\title{
Synthesis and photovoltaic performance of DPP-based small molecules with tunable energy levels by altering the molecular terminals
}

\author{
Delong Yu ${ }^{a}$, Yu Liu ${ }^{\text {a, }}{ }^{*}$, Manjun Xiao a , Qunping Fan ${ }^{a}$, Wenyan $\mathrm{Su}^{\text {a }}$, Xiao Li ${ }^{\text {a }}$, Hua Tan ${ }^{\mathrm{a}}$, \\ Yafei Wang ${ }^{\mathrm{a}}$, Renqiang Yang ${ }^{\mathrm{b}, * *}$, Weiguo $\mathrm{Zhu}^{\mathrm{a}}{ }^{\mathrm{a} * * *}$ \\ a College of Chemistry, Xiangtan University, Key Lab of Environment-Friendly Chemistry and Application in Ministry of Education, Xiangtan 411105, China \\ ${ }^{\mathrm{b}}$ Qingdao Institute of Bioenergy and Bioprocess Technology, Chinese Academy of Sciences, Qingdao 266101, China
}

\section{A R T I C L E I N F O}

\section{Article history:}

Received 23 July 2015

Received in revised form

6 September 2015

Accepted 8 October 2015

Available online 26 October 2015

\section{Keywords:}

Organic solar cells

Small molecules

Bulk-heterojunction

Diketopyrrolopyrrole

Pyrene

Rodanine

\begin{abstract}
A B S T R A C T
Four novel small molecules, $\mathrm{Ph}(\mathrm{DPP}-\mathrm{Th})_{2}, \mathrm{Ph}(\mathrm{DPP}-\mathrm{Py})_{2}, \mathrm{Ph}(\mathrm{DPP}-\mathrm{ThCN})_{2}$ and $\mathrm{Ph}(\mathrm{DPP}-\mathrm{ThR})_{2}$ were synthesized and characterized, in which diketopyrrolopyrrole-phenyl-diketopyrrolopyrrole was used as the core, donor units of 2-octylthiophene (Th), pyrene (Py), acceptor units octyl 2-cyano-3-(thiophen-2-yl)acrylate (ThCN) and 3-octyl-5-(thiophen-2-ylmethylene)rodanine (ThR) were used as the terminals, respectively. By changing the terminals of small molecules, their corresponding thermal, absorptive, electro-chemical and photovoltaic properties were rationally adjusted for applications as donor materials in organic solar cells (OSCs). All of small molecules exhibit broad absorption spectra from the visible to near-infrared region, and $\mathrm{Ph}(\mathrm{DPP}-\mathrm{ThR})_{2}$ showed the minimum optical band gap of $1.48 \mathrm{eV}$. The small molecules with acceptor terminal units had much deeper HOMO energy levels than those with donor terminal units, which is important to increase the open-circuit voltage $\left(V_{\mathrm{oc}}\right)$. A maximum power conversion efficiency of $3.22 \%$, short-circuit current density of $10.55 \mathrm{~mA} \mathrm{~cm}^{-2}, V_{\mathrm{oc}}$ of $0.85 \mathrm{~V}$, and fill factor of $39 \%$ were obtained in the $\mathrm{Ph}(\mathrm{DPP}-\mathrm{Py})_{2} / \mathrm{PC}_{71} \mathrm{BM}$ based cells under AM $1.5 \mathrm{G}$ irradiation $\left(100 \mathrm{~mW} \mathrm{~cm}^{-1}\right)$. These results demonstrate valuable guidelines for the rational design of solution-processed small molecules for OSCs.
\end{abstract}

(c) 2015 Elsevier Ltd. All rights reserved.

\section{Introduction}

In the past few decades, solution-processed organic solar cells (OSCs), as a promising alternative to traditional silicon solar cells for addressing the global energy crisis, have received tremendous interest and attention due to their low cost, light weight, and flexibility in large-area applications [1-6]. At the same time, significant progress has been made for polymer solar cells (PSCs), such as the development of highly promising bulk-heterojunction (BHJ) structures and power conversion efficiencies (PCE) above 10\% [7-9]. So far, solution-processed small molecules based OSCs (SMOSCs) have demonstrated PCE over 10\% [10,11], but their

\footnotetext{
* Corresponding author. Tel.: +86 731 58293377; fax: +86 73158292251.

** Corresponding author. Tel.: +86 731 58293377; fax: +86 73158292251.

*** Corresponding author. Tel.: +86 731 58293377; fax: +86 73158292251 .

E-mail addresses: liuyu03b@126.com (Y. Liu), yangrq@qibebt.ac.cn (R. Yang), zhuwg18@126.com (W. Zhu).
}

photovoltaic performance is still behind that of polymer based PSCs. Recently, SM-OSCs have come to great attention due to their merits of well-defined molecular structure, definite molecular weight, easier purification, and improved batch to batch reproducibility. Therefore, the design and synthesis of superior materials present a great challenge in which accurate guidelines are yet to be determined [12,13].

Diketopyrrolopyrrole (DPP) is a promising type of acceptor unit for organic optoelectronic applications due to its strong light absorption, unique $\pi$-conjugated system, photochemical stability, and large-scale synthesis [14-17]. DPP is a strong electron-withdrawing moiety with exceptional stability and has been coupled with a variety of electron-rich groups to provide low band gap polymers and small molecules for BHJ solar cells [18-20], organic field effect transistors (OFETs) [21,22], dye-sensitized solar cells (DSSCs) $[23,24]$, and chemical sensors [25]. Furthermore, introducing planar heteroarene DPP units into $\pi$-conjugated system backbones has been shown to improve relational characteristics, such as 
higher charge mobility and broader light absorption due to increasing the effective conjugation length by facilitating $\pi$-electron delocalization. Considering these merits and characteristics, star-shaped and linear small molecules were rapidly developed by using DPP as molecular building blocks and exhibited favorable photovoltaic performances [26-28]. Nevertheless, to our knowledge, there is less reported about arene-diketopyrrolopyrrole- $\pi$ diketopyrrolopyrrole-arene (Ar-DPP- $\pi$-DPP-Ar)-type framework, in which $\mathrm{Ar}$ is different conjugated molecular terminals, as the small molecular building block for applications in OSCs.

Conventionally, coupling strong acceptor units and weak donor units serves to broaden the absorption spectra, decrease the highest occupied molecular orbital (HOMO) energy levels, and improve the photovoltaic performances. Planar acceptor units as molecular terminal groups (such as cyanoacetate, 3ethylrhodanine, thiobarbituric acid, indenedione) have a broad absorption spectra, low HOMO energy levels, high hole mobilities and good photovoltaic performances [29-32]. In contrast, pyrene (Py) has intense $\pi-\pi$ stacking interactions due to its planar structure, an enlarged $\pi$-conjugation system, and a relatively low HOMO energy level [33-36]. Incorporating planar Py as molecular terminal groups is considered to be favorable for enhancing molecular self-assembly [37]. Previous studies have also shown that $\pi$ extended Py derivatives usually exhibit significantly higher carrier mobilities and are used in organic thin film transistors (OTFTs) $[38,39]$ and in organic photovoltaics (OPV) [40].

For better understanding the influence of different conjugated molecular terminals on the properties of diketopyrrolopyrrolephenyl-diketopyrrolopyrrole (DPP-Ph-DPP)-based small molecules, we synthesized and characterized four novel DPP-based small molecules of Ph(DPP-Th $)_{2}, \mathrm{Ph}(\mathrm{DPP}-\mathrm{Py})_{2}, \mathrm{Ph}(\mathrm{DPP}-\mathrm{ThCN})_{2}$ and $\mathrm{Ph}$ (DPP-ThR $)_{2}$, in which DPP-Ph-DPP was used as the core, and 2octylthiophene (Th), Py, octyl 2-cyano-3-(thiophen-2-yl)acrylate (ThCN), and 3-octyl-5-(thiophen-2-ylmethylene)rodanine (ThR) were used as the different molecular terminals (see Scheme 1), respectively. By changing the terminals of these small molecules, their thermal, absorptive, electro-chemical, and photovoltaic properties could be rationally adjusted for applications in OSCs. All of SMs exhibited broad absorption spectra from the visible to nearinfrared region, and $\mathrm{Ph}(\mathrm{DPP}-\mathrm{ThR})_{2}$ had the minimum optical band gap of $1.48 \mathrm{eV}$. The SMs with acceptor terminal units (ThCN or ThR) had much deeper HOMO energy levels than those with donor terminal units (Py or Th), which helped to increase the open-circuit voltage $\left(V_{\mathrm{oc}}\right)$. A maximum PCE of $3.22 \%$, short-circuit current density $\left(J_{\mathrm{sc}}\right)$ of $10.55 \mathrm{~mA} \mathrm{~cm}{ }^{-2}, V_{\mathrm{oc}}$ of $0.85 \mathrm{~V}$, and fill factor $(F F)$ of $39 \%$ were obtained in the $\mathrm{Ph}(\mathrm{DPP}-\mathrm{Py})_{2} / \mathrm{PC}_{71} \mathrm{BM}$ based solar cells. Our study offers a valuable guideline for designing Ar-DPP- $\pi$-DPP-Ar based small molecules for high-performance OSCs.

\section{Experimental section}

\subsection{Materials}

Commercially available chemicals were purchased from commercial sources and used without further purification unless otherwise specified. All solvents were dried over sodium and freshly distilled prior to use. Compounds Ph(DPP-Br)2 [4], 2 [41], 3 [42] and 5 [43] were synthesized following the same procedure as reported in the literature.

\subsection{Measurements and characterization}

Nuclear magnetic resonance (NMR) spectra were recorded on a Bruker DRX 400 spectrometer using tetramethylsilane (TMS) as a reference in deuterated chloroform $\left(\mathrm{CHCl}_{3}\right)$ solution at $298 \mathrm{~K}$.
MALDI-TOF mass spectrometric measurements were performed on Bruker Bifiex III MALDI TOF. Elemental analyses were carried out with a Harrios elemental analysis instrument. Thermogravimetric analysis (TGA) was conducted under a dry nitrogen gas flow at a heating rate of $20{ }^{\circ} \mathrm{C} \mathrm{min}-1$ on a Perkin-Elmer TGA 7. UV-Vis absorption spectra were recorded on a HP-8453 UV visible system. Cyclic voltammograms (CV) were carried out on a CHI660A electrochemical work station with a three electrode electrochemical cell in a $0.1 \mathrm{M}$ tetrabutylammonium hexafluorophosphate $\left(\mathrm{TBAPF}_{6}\right)$ acetonitrile solution with a scan $100 \mathrm{mV} \mathrm{s}^{-1}$ at room temperature (RT) under argon atmosphere. In this three-electrode cell, a platinum rod, platinum wire and $\mathrm{Ag} / \mathrm{AgCl}$ electrode were used as a working electrode, counter electrode and reference electrode, respectively. The surface morphologies were recorded by atomic force microscopy (AFM) on a Veeco, DI multimode NS-3D apparatus in a trapping mode under normal air condition at RT with a $5 \mu \mathrm{m}$ scanner.

\subsection{Device fabrication and characterization}

The photovoltaic cells were fabricated using indium tin oxide (ITO) glass as an anode, $\mathrm{Ca} / \mathrm{Al}$ as a cathode, and a blend film of the small molecule/PCBM as a photosensitive layer. After a $30 \mathrm{~nm}$ buffer layer of poly-(3,4-ethylenedioxy-thiophene) and polystyrene sulfonic acid (PEDOT:PSS) was spin-coated onto the precleaned ITO substrate, the photosensitive layer was subsequently prepared by spin-coating a solution of the small molecule/PCBM in chloroform on the PEDOT:PSS layer. Ca (10 nm) and $\mathrm{Al}(100 \mathrm{~nm})$ were successively deposited on the photosensitive layer in vacuum and used as top electrodes. The current-voltage $(I-V)$ characterization of the devices was carried out on a computer-controlled Keithley source measurement system. A solar simulator was used as the light source and the light intensity was monitored by a standard Si solar cell. The active area was $1 \times 10^{-2} \mathrm{~cm}^{2}$ for each cell. The thicknesses of the spun-cast films were recorded by a profilometer (Alpha-Step 200, Tencor Instruments). The external quantum efficiency (EQE) was measured with a Stanford Research Systems model SR830 DSP lock-in amplifier coupled with WDG3 monochromator and a $150 \mathrm{~W}$ xenon lamp.

\subsection{Synthesis of target molecules}

\subsubsection{Synthesis of $P h(D P P-T h)_{2}$}

To a mixture of compound $\mathrm{Ph}(\mathrm{DPP}-\mathrm{Br})_{2}$ (420 mg, $\left.0.33 \mathrm{mmol}\right), 2$ (397 mg, $0.82 \mathrm{~mol}$ ), tetrakis(triphenylphosphine)palladium $\left(\mathrm{Pd}\left(\mathrm{PPh}_{3}\right)_{4}, 20 \mathrm{mg}, 0.02 \mathrm{mmol}\right)$ was dissolved in a degassed mixture of toluene $(20 \mathrm{~mL})$. The reaction mixture was heated to reflux for $24 \mathrm{~h}$ by stirring under nitrogen atmosphere. After cooling down to $\mathrm{RT}$, the mixture was quenched with water $(100 \mathrm{~mL})$ and extracted with $\mathrm{CHCl}_{3}(3 \times 50 \mathrm{~mL})$ and then combined organic layer was dried over anhydrous magnesium sulfate $\left(\mathrm{MgSO}_{4}\right)$. The solvent was removed off under reduced pressure by rotary evaporation and the residue was purified through a flash silica gel column with dichloromethane/petroleum ether (DCM/PE, $V / V, 3: 2)$ as the eluent to give a dark blue solid (320 mg, yield $75 \%) .{ }^{1} \mathrm{H}$ NMR $\left(\mathrm{CDCl}_{3}\right.$, $400 \mathrm{MHz}), \delta(\mathrm{ppm}): 8.90(\mathrm{~s}, 2 \mathrm{H}), 7.68(\mathrm{~s}, 4 \mathrm{H}), 8.20$ (s, 2H), 7.49 (d, $J=4.0 \mathrm{~Hz}, 2 \mathrm{H}), 7.21(\mathrm{~d}, J=4.0 \mathrm{~Hz}, 2 \mathrm{H}), 7.12(\mathrm{~d}, J=4.0 \mathrm{~Hz}, 2 \mathrm{H}), 6.72$ $(\mathrm{d}, J=4.0 \mathrm{~Hz}, 2 \mathrm{H}), 4.06(\mathrm{~m}, 4 \mathrm{H}), 2.80(\mathrm{t}, J=8.0 \mathrm{~Hz}, 2 \mathrm{H}), 1.93(\mathrm{~s}, 1 \mathrm{H})$, 0.87-1.71 (m,14H). MALDI-MS $(\mathrm{m} / \mathrm{z})$ : 1512.760 for $\left[\mathrm{M}^{+}\right]$. Anal. Calcd for: $\mathrm{C}_{90} \mathrm{H}_{118} \mathrm{~N}_{4} \mathrm{O}_{4} \mathrm{~S}_{6}$ : C, 71.48; H, 7.86; N, 3.70; S, 12.72. Found: $\mathrm{C}$, $71.01 ; \mathrm{H}, 8.65 ; \mathrm{N}, 3.58 ; \mathrm{S}, 8.65$.

\subsubsection{Synthesis of $P h(D P P-P y)_{2}$}

To a mixture of compound $\mathrm{Ph}(\mathrm{DPP}-\mathrm{Br})_{2}(300 \mathrm{mg}, 0.23 \mathrm{mmol}), 3$ (232 mg, $0.71 \mathrm{mmol}), \mathrm{Pd}\left(\mathrm{PPh}_{3}\right)_{4}(14 \mathrm{mg}, 0.02 \mathrm{mmol})$, potassium 

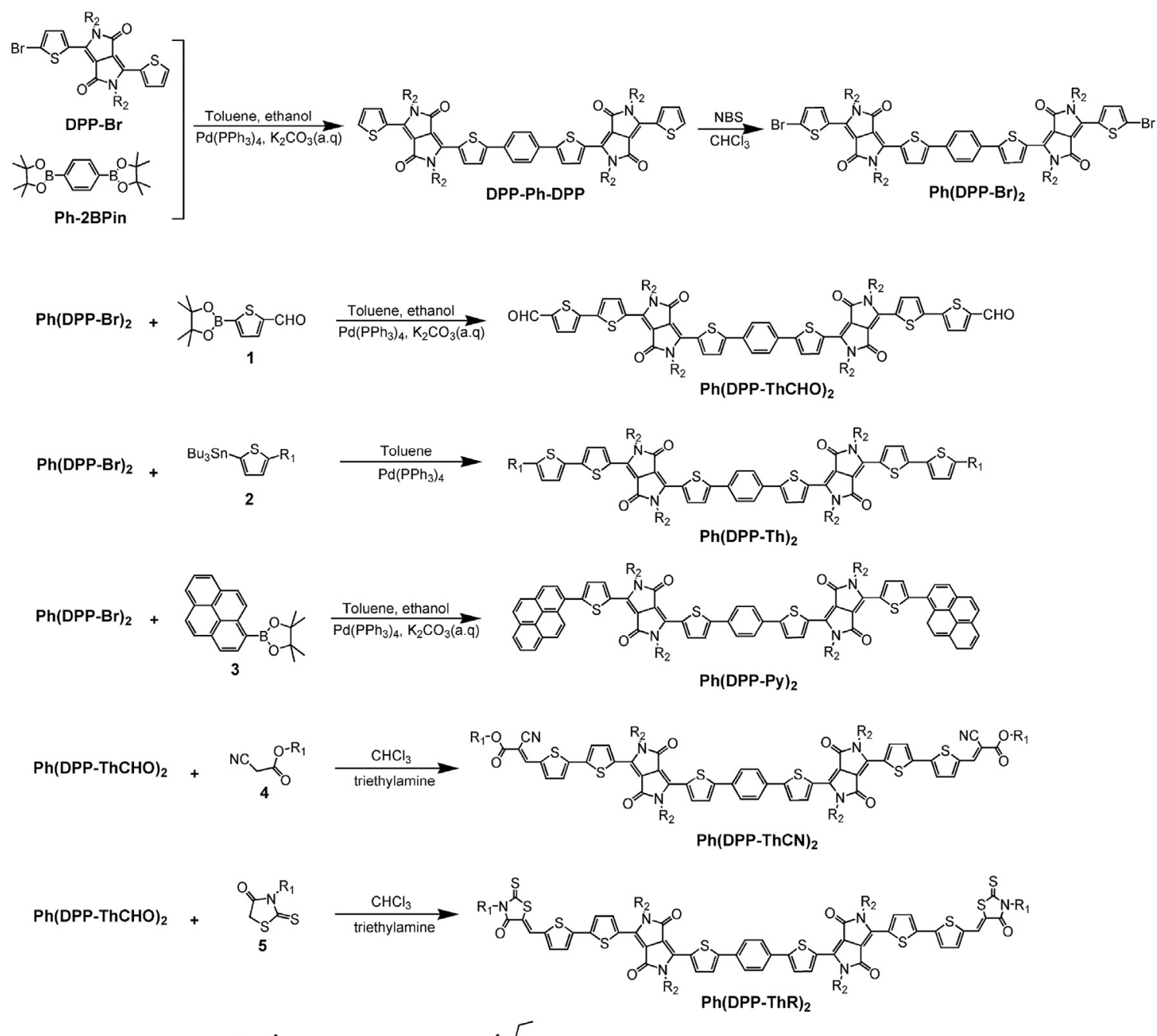

$\mathrm{R}_{1}=3$ (2)

Scheme 1. Synthetic routes of the DPP-Ph-DPP-based small molecules.

carbonate solution ( $2 \mathrm{M}, 4 \mathrm{~mL}$ ) was dissolved in a degassed mixture of toluene $(20 \mathrm{~mL})$ and aqueous ethanol $(8 \mathrm{~mL})$. The reaction mixture was heated to reflux for $24 \mathrm{~h}$ by stirring under nitrogen atmosphere. After cooling down to RT, the mixture was quenched with water $(100 \mathrm{~mL})$ and extracted with $\mathrm{CHCl}_{3}(3 \times 50 \mathrm{~mL})$ and then combined organic layer was dried over anhydrous $\mathrm{MgSO}_{4}$. The solvent was removed off under reduced pressure by rotary evaporation and the residue was purified through a flash silica gel column with $\mathrm{DCM} / \mathrm{PE}(V / V, 3: 2)$ as the eluent to give a dark blue solid (214 mg, yield 61\%). ${ }^{1} \mathrm{H}$ NMR ( $\left.\mathrm{CDCl}_{3}, 400 \mathrm{MHz}\right), \delta(\mathrm{ppm}): 9.16$ (d, $J=4.0 \mathrm{~Hz}, 2 \mathrm{H}), 9.01(\mathrm{~d}, J=4.0 \mathrm{~Hz}, 2 \mathrm{H}), 8.54(\mathrm{~d}, J=12.0 \mathrm{~Hz}, 2 \mathrm{H})$, 8.04-8.22 (m, 18H), $7.70(\mathrm{~s}, 4 \mathrm{H}), 7.57$ (d, $J=4.0 \mathrm{~Hz}, 2 \mathrm{H}), 7.52(\mathrm{~d}$, $J=4.0 \mathrm{~Hz}, 2 \mathrm{H}), 4.10(\mathrm{~s}, 2 \mathrm{H}), 0.87-1.44(\mathrm{~m}, 16 \mathrm{H})$. MALDI-MS $(\mathrm{m} / \mathrm{z})$ : 1522.643 for $\left[\mathrm{M}^{+}\right]$. Anal. Calcd for: $\mathrm{C}_{98} \mathrm{H}_{98} \mathrm{~N}_{4} \mathrm{O}_{4} \mathrm{~S}_{4}: \mathrm{C}, 77.23 ; \mathrm{H}, 6.48$; N, 3.68; S, 8.42. Found: C, 74.11; H, 6.95; N, 3.44; S, 8.23.

\subsubsection{Synthesis of $P h(D P P-T h C N)_{2}$}

To a mixture of compound $\mathrm{Ph}(\mathrm{DPP}-\mathrm{ThCHO})_{2}(100 \mathrm{mg}$, $0.07 \mathrm{mmol}), 4$ (366 $\mathrm{mg}, 1.86 \mathrm{mmol})$, triethylamine $(1.5 \mathrm{~mL})$ were dissolved in dry $\mathrm{CHCl}_{3}(20 \mathrm{~mL})$. The reaction mixture was heated to reflux for $48 \mathrm{~h}$ by stirring under nitrogen atmosphere. After cooling down to RT, the mixture was quenched with water $(100 \mathrm{~mL})$ and extracted with $\mathrm{CHCl}_{3}(3 \times 20 \mathrm{~mL})$ and then combined organic layer was dried over anhydrous $\mathrm{MgSO}_{4}$. The solvent was removed off under reduced pressure by rotary evaporation and the residue was purified through a flash silica gel column with DCM/ethyl acetate (EA) $(V / V, 40 / 1)$ as the eluent to give a dark green solid (77 mg, yield 61\%). ${ }^{1} \mathrm{H} \mathrm{NMR}\left(\mathrm{CDCl}_{3}, 400 \mathrm{MHz}\right), \delta(\mathrm{ppm}): 9.05$ (d, $\left.J=3.2 \mathrm{~Hz}, 2 \mathrm{H}\right)$, $8.98(\mathrm{~d}, J=4.0 \mathrm{~Hz}, 2 \mathrm{H}), 8.20(\mathrm{~s}, 2 \mathrm{H}), 7.68(\mathrm{~d}, J=4.0 \mathrm{~Hz}, 2 \mathrm{H}), 7.95(\mathrm{~d}$, $J=7.2 \mathrm{~Hz}, 1 \mathrm{H}), 7.61(\mathrm{~s}, 4 \mathrm{H}), 7.47(\mathrm{~d}, J=4.0 \mathrm{~Hz}, 2 \mathrm{H}), 7.42(\mathrm{~d}, J=4.0 \mathrm{~Hz}$, $2 \mathrm{H}), 7.32$ (d, $J=4.0 \mathrm{~Hz}, 2 \mathrm{H}), 4.27(\mathrm{t}, J=8.0 \mathrm{~Hz}, 2 \mathrm{H}), 4.04(\mathrm{~s}, 2 \mathrm{H})$, $1.90-2.04(\mathrm{~m}, 8 \mathrm{H}), 0.9-1.39(\mathrm{~m}, 8 \mathrm{H})$. MALDI-MS $(\mathrm{m} / \mathrm{z}): 1702.942$ for $\left[\mathrm{M}^{+}\right]$. Anal. Calcd for: $\mathrm{C}_{98} \mathrm{H}_{120} \mathrm{~N}_{6} \mathrm{O}_{8} \mathrm{~S}_{6}: \mathrm{C}, 69.14 ; \mathrm{H}, 7.10 ; \mathrm{N}, 4.94 ; \mathrm{S}$, 11.30. Found: C, 69.75; H, 7.99; N, 4.56; S, 10.67 .

\subsubsection{Synthesis of $P h(D P P-T h R)_{2}$}

To a mixture of compound $\mathrm{Ph}(\mathrm{DPP}-\mathrm{ThCHO})_{2}$ (100 mg, $0.07 \mathrm{mmol}), 5$ (365 mg, $1.48 \mathrm{mmol})$, triethylamine $(1.5 \mathrm{~mL}$ ) were dissolved in dry $\mathrm{CHCl}_{3}(20 \mathrm{~mL})$. The reaction mixture was heated to reflux for $48 \mathrm{~h}$ by stirring under nitrogen atmosphere. After cooling down to RT, the mixture was quenched with water $(100 \mathrm{~mL})$ and extracted with $\mathrm{CHCl}_{3}(3 \times 20 \mathrm{~mL})$ and then combined organic layer was dried over anhydrous $\mathrm{MgSO}_{4}$. The solvent was removed off under reduced pressure by rotary evaporation and the residue was purified through a flash silica gel column with DCM/EA (V/V, 40/1) as the eluent to give a brown green solid (63 mg, yield $47 \%$ ). ${ }^{1} \mathrm{H}$ NMR $\left(\mathrm{CDCl}_{3}, 400 \mathrm{MHz}\right), \delta(\mathrm{ppm}): 9.04(\mathrm{~d}, J=4.0 \mathrm{~Hz}, 2 \mathrm{H}), 8.93(\mathrm{~d}$, $J=4.0 \mathrm{~Hz}, 2 \mathrm{H}), 7.77(\mathrm{~s}, 4 \mathrm{H}), 7.66(\mathrm{~d}, J=20.0 \mathrm{~Hz}, 2 \mathrm{H}), 7.50$ (d, 


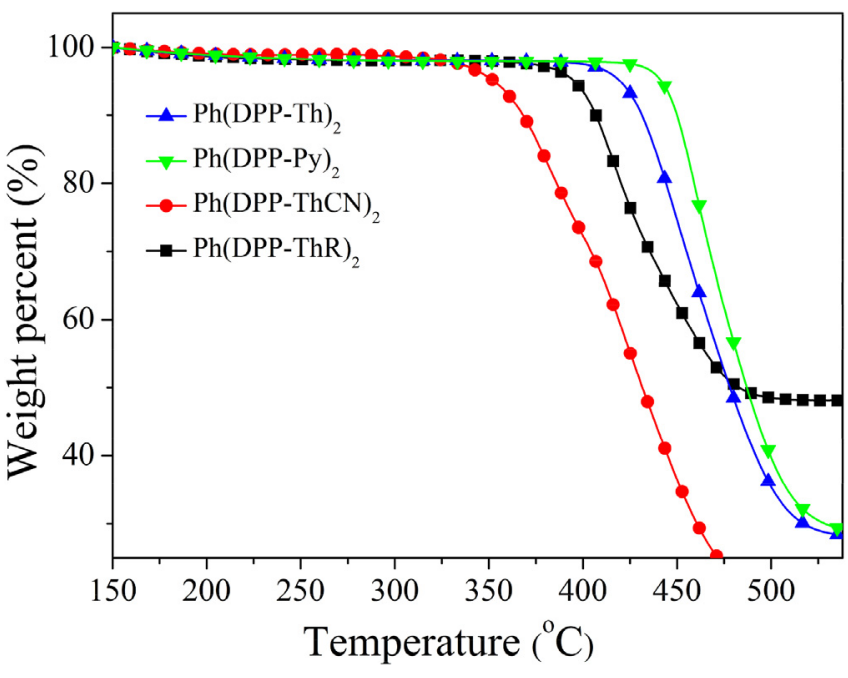

Fig. 1. TGA curves of the small molecules.

$J=8.0 \mathrm{~Hz}, 2 \mathrm{H}), 7.32(\mathrm{~s}, 2 \mathrm{H}), 4.05(\mathrm{~s}, 2 \mathrm{H}), 2.03(\mathrm{~s}, 1 \mathrm{H}), 1.92(\mathrm{~s}, 1 \mathrm{H}), 1.67$ (S, 1H), 0.71-1.25 (m, 17H). MALDI-MS $(\mathrm{m} / z)$ : 1798.028 for $\left[\mathrm{M}^{+}\right]$. Anal. Calcd for: $\mathrm{C}_{98} \mathrm{H}_{120} \mathrm{~N}_{6} \mathrm{O}_{6} \mathrm{~S}_{10}$ : C, 65.44; $\mathrm{H}, 6.72 ; \mathrm{N}, 4.67 ; \mathrm{S}, 17.83$. Found: C, 65.09; H, 6.35; N, 4.48; S, 17.52.

\section{Results discussion}

\subsection{Synthesis and thermal property}

The general synthetic routes for small molecules are outlined in Scheme 1. The detailed procedures of the monomer Ph(DPP$\mathrm{ThCHO})_{2}$ are shown in the electronic supporting information (ESI). The target compounds of $\mathrm{Ph}(\mathrm{DPP}-\mathrm{Py})_{2}, \mathrm{Ph}(\mathrm{DPP}-\mathrm{Th})_{2}, \mathrm{Ph}(\mathrm{DPP}-$ ThCN $)_{2}$ and $\mathrm{Ph}(\mathrm{DPP}-\mathrm{ThR})_{2}$ were synthesized with yields of $75 \%, 61 \%$, $61 \%$ and $47 \%$, respectively. Their structures are consistent with molecular formulas characterized by elemental analysis, ${ }^{1} \mathrm{H}$ NMR and MALDI-MS (ESI).

The thermal stability of these small molecules was investigated by TGA under the atmosphere of nitrogen, and corresponding curves and data were depicted in Fig. 1 and Table 1. The thermal decomposition temperatures $\left(T_{\mathrm{d}}\right)$ for $\mathrm{Ph}(\mathrm{DPP}-\mathrm{Th})_{2}, \mathrm{Ph}(\mathrm{DPP}-\mathrm{Py})_{2}$, $\mathrm{Ph}(\mathrm{DPP}-\mathrm{ThCN})_{2}$ and $\mathrm{Ph}(\mathrm{DPP}-\mathrm{ThR})_{2}$ are $410,434,344$ and $386{ }^{\circ} \mathrm{C}$ at $5 \%$ weight loss, respectively. Compared to the $\mathrm{Ph}(\mathrm{DPP}-\mathrm{ThCN})_{2}$ and $\mathrm{Ph}(\mathrm{DPP}-\mathrm{ThR})_{2}$ with the terminal acceptors of ThCN and ThR, $\mathrm{Ph}(\mathrm{DPP}-\mathrm{Th})_{2}$ and $\mathrm{Ph}(\mathrm{DPP}-\mathrm{Py})_{2}$ with the terminal donors of Th and Py exhibit increased $T_{\mathrm{d}}$ values, which means that two terminal donors play a positive role in increasing thermal stability of its small molecules with DPP-Ph-DPP building block central core. All of SMs have a good enough thermal stability for their application in optoelectronic devices.

\subsection{Optical properties}

The absorption spectra of these SMs in dilute $\mathrm{CHCl}_{3}$ solutions and thin solid films are shown in Fig. 2. The detailed parameters are summarized in Table 1. All of SMs exhibited strong and broad absorption bands in the visible to near-infrared region. In a solution, all of these SMs exhibited similar absorbance spectra that feature two unique bands. The high-energy absorption band from 340 to $500 \mathrm{~nm}$ was assigned to the $\pi-\pi$ transition and the low-energy absorption band from 500 to $750 \mathrm{~nm}$ was attributed to strong photoinduced the intramolecular charge-transfer (ICT). Compared to $\mathrm{Ph}(\mathrm{DPP}-\mathrm{Th})_{2}$ and $\mathrm{Ph}(\mathrm{DPP}-\mathrm{Py})_{2}$, the absorption spectra of $\mathrm{Ph}$ (DPP$\mathrm{ThCN})_{2}$ and $\mathrm{Ph}(\mathrm{DPP}-\mathrm{ThR})_{2}$ shift to longer wavelengths by
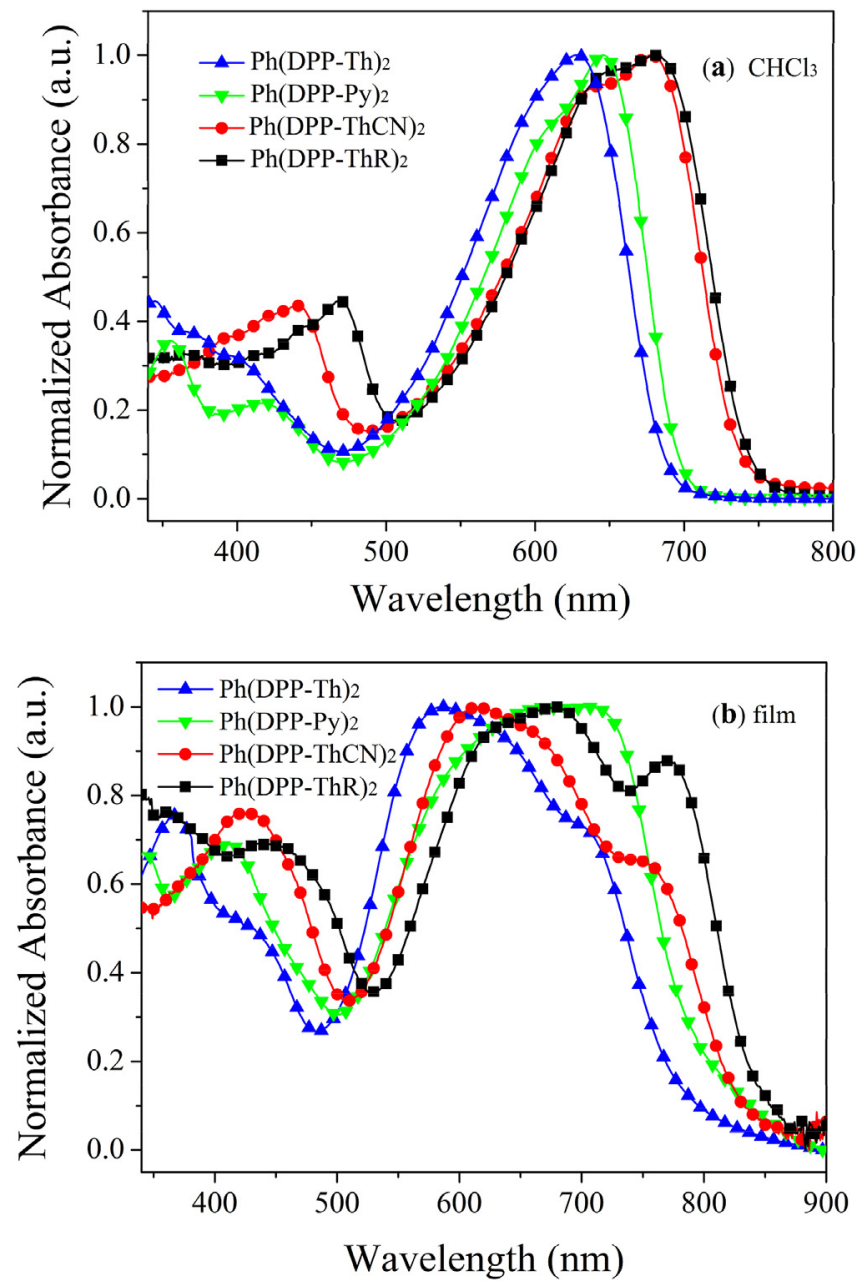

Fig. 2. UV-Vis absorption spectra of the small molecules in $\mathrm{CHCl}_{3}$ (a) and in thin films (b), respectively.

Table 1

Electrochemical, optical and thermal propertiess of the small molecules.

\begin{tabular}{|c|c|c|c|c|c|c|c|c|}
\hline Compounds & $\begin{array}{l}\lambda_{\mathrm{abs}} \\
/ \mathrm{nm}^{\mathrm{a}}\end{array}$ & $\begin{array}{l}\lambda_{\mathrm{abs}} \\
/ \mathrm{nm}^{\mathrm{b}}\end{array}$ & $\begin{array}{l}\lambda_{\text {onset }} \\
/ \mathrm{nm}\end{array}$ & $\begin{array}{l}E_{\mathrm{g}}^{\mathrm{opt}} \\
/ \mathrm{eV}^{\mathrm{c}}\end{array}$ & $\begin{array}{l}E_{\text {HOMо }} \\
/ \mathrm{eV}\end{array}$ & $\begin{array}{l}E_{\text {LUMO }} \\
/ \mathrm{eV}\end{array}$ & $\begin{array}{l}E_{\mathrm{g}}^{\mathrm{ev}} \\
/ \mathrm{eV}\end{array}$ & $\begin{array}{l}\mathrm{T}_{\mathrm{d}} \\
1{ }^{\circ} \mathrm{C}\end{array}$ \\
\hline $\mathrm{Ph}(\mathrm{DPP}-\mathrm{Th})_{2}$ & 342,630 & $367,585,698$ & 790 & 1.57 & -5.27 & -3.34 & 1.93 & 410 \\
\hline $\mathrm{Ph}(\mathrm{DPP}-\mathrm{Py})_{2}$ & 353,647 & $413,661,708$ & 821 & 1.51 & -5.30 & -3.16 & 2.14 & 434 \\
\hline $\mathrm{Ph}(\mathrm{DPP}-\mathrm{ThCN})_{2}$ & 439,679 & $427,616,747$ & 837 & 1.48 & -5.42 & -3.45 & 1.97 & 344 \\
\hline $\mathrm{Ph}(\mathrm{DPP}-\mathrm{ThR})_{2}$ & 468,680 & $445,678,771$ & 860 & 1.44 & -5.35 & -3.44 & 1.91 & 386 \\
\hline
\end{tabular}

a Measured in $\mathrm{CHCl}_{3}$.

b Measured in the neat film.

c $E_{\mathrm{g}}^{\mathrm{opt}}=1240 / \lambda_{\text {onset }}$. 


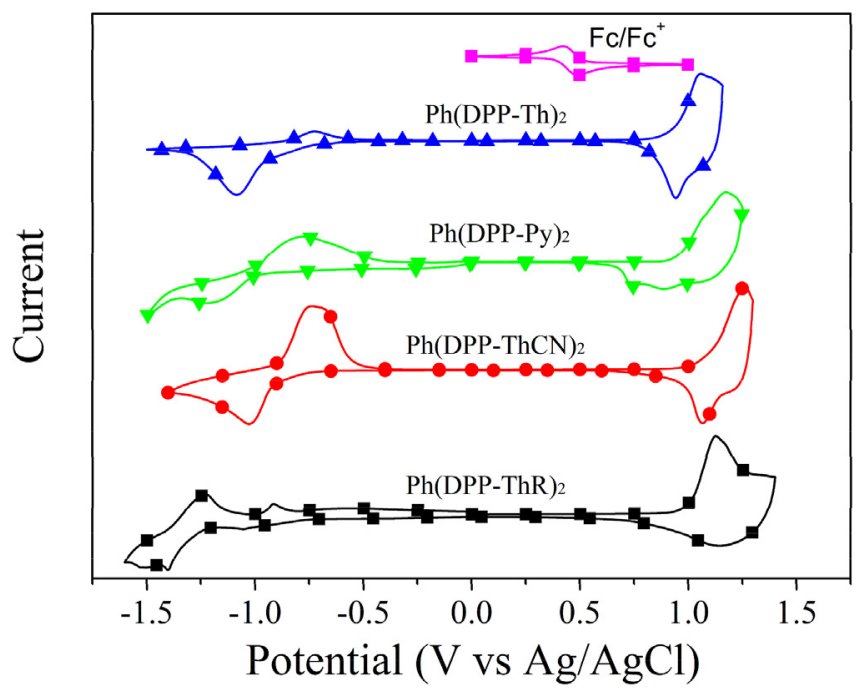

Fig. 3. Cyclic voltammogram curves of the small molecules.

introducing electron-withdrawing units ThCN and ThR to the DPPPh-DPP-based SMs (Fig. 2a).

Compared to the absorption spectra in $\mathrm{CHCl}_{3}$ solution, $\mathrm{Ph}$ (DPP$\mathrm{Th})_{2}, \mathrm{Ph}(\mathrm{DPP}-\mathrm{Py})_{2}, \mathrm{Ph}(\mathrm{DPP}-\mathrm{ThCN})_{2}$ and $\mathrm{Ph}(\mathrm{DPP}-\mathrm{ThR})_{2}$ in neat films showed $60-90 \mathrm{~nm}$ red-shifted peaks in the long wavelength region, an additional shoulder peak at 585, 661, 616 and $678 \mathrm{~nm}$, and a red-shift high energy peak of 698, 708, 747 and $771 \mathrm{~nm}$ (Fig. 2b), suggesting that these SMs possess strong intermolecular packing potentials in a solid state. Based on the onset of the film absorption, the optical band gaps $\left(E_{\mathrm{g}}^{\mathrm{opt}}\right)$ of Ph(DPP-Th $)_{2}, \mathrm{Ph}(\mathrm{DPP}-\mathrm{Py})_{2}, \mathrm{Ph}(\mathrm{DPP}-$ ThCN $)_{2}$ and $\mathrm{Ph}(\mathrm{DPP}-\mathrm{ThR})_{2}$ were calculated to be $1.57,1.51,1.48$ and $1.44 \mathrm{eV}$, respectively. The extended absorption edge in the long wavelength region was attributed to the aggregated configurations in the solid state.

\subsection{Electrochemical properties}

The electrochemical properties of these small molecules was investigated by cyclic voltammetry (CV) using an $\mathrm{Ag} / \mathrm{AgCl}$ electrode as a reference and the redox potential of ferrocene/ferrocenium $(\mathrm{Fc})$

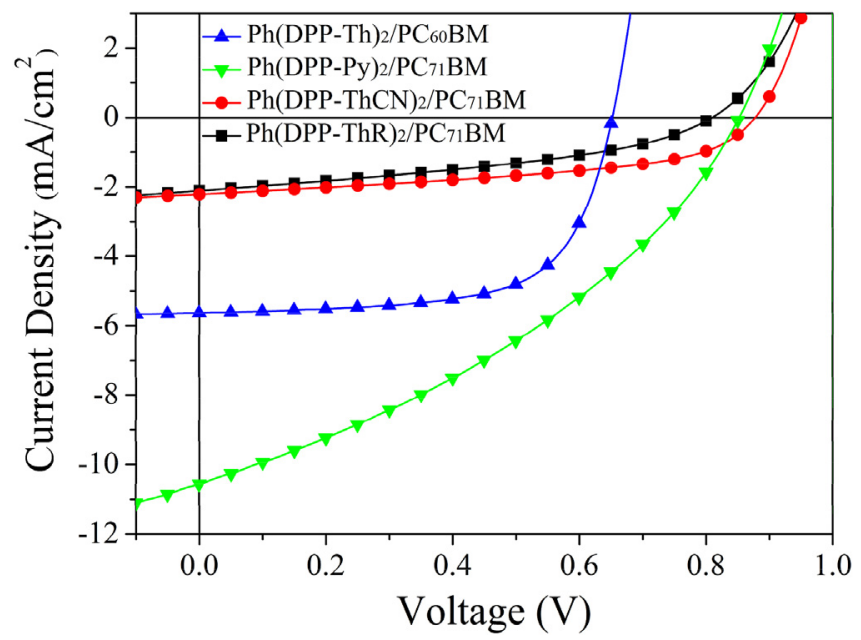

Fig. 4. $J-V$ curves of the small molecules/PCBM-based at optimized conditions under illumination of $\mathrm{AM} 1.5 \mathrm{G}, 100 \mathrm{~mW} \mathrm{~cm}^{-2}$.
Table 2

Photovoltaic performance of the small molecules/PCBM-based solar cells under illumination of AM $1.5 \mathrm{G}, 100 \mathrm{~mW} \mathrm{~cm}^{-2}$.

\begin{tabular}{lllcll}
\hline Active layers & $\begin{array}{l}\mathrm{D} / \mathrm{A} \\
(\mathrm{w} / \mathrm{w})\end{array}$ & $V_{\mathrm{oc}}(\mathrm{V})$ & $\begin{array}{l}J_{\mathrm{sc}} \\
\left.(\mathrm{mA} \mathrm{cm})^{-2}\right)\end{array}$ & $\begin{array}{l}F F \\
(\%)\end{array}$ & $\begin{array}{l}\mathrm{PCE}_{\max } \\
(\%)\end{array}$ \\
\hline $\mathrm{Ph}(\mathrm{DPP}-\mathrm{Th})_{2}: \mathrm{PC}_{60} \mathrm{BM}^{\mathrm{a}}$ & $3: 2$ & 0.65 & 5.63 & 66 & 2.41 \\
$\mathrm{Ph}(\mathrm{DPP}-\mathrm{Py})_{2}: \mathrm{PC}_{71} \mathrm{BM}^{\mathrm{b}}$ & $1: 3$ & 0.85 & 10.55 & 39 & 3.22 \\
$\mathrm{Ph}(\mathrm{DPP}-\mathrm{ThCN})_{2}: \mathrm{PC}_{71} \mathrm{BM}^{\mathrm{c}, \mathrm{d}}$ & $1: 1$ & 0.88 & 2.21 & 49 & 0.95 \\
$\mathrm{Ph}(\mathrm{DPP}-T h R)_{2}: \mathrm{PC}_{71} \mathrm{BM}^{\mathrm{d}}$ & $1: 2$ & 0.81 & 2.11 & 39 & 0.67 \\
\hline
\end{tabular}

a Annealing at $110{ }^{\circ} \mathrm{C}$

b Speed/rpm (3000).

c Annealing at $70{ }^{\circ} \mathrm{C}$.

d $1 \%$ DIO additive.

$\mathrm{Fc}+$ ) as a calibrated standard. Fig. 3 shows the recorded CV curves of these small molecules and the relevant data are summarized in Table 1. The HOMO and the lowest unoccupied molecular orbital (LUMO) energy levels of the four small molecules were calculated from the onset of oxidation $\left(E_{\mathrm{ox}}\right)$ and reduction $\left(E_{\mathrm{red}}\right)$ values by using the following empirical equations [44]: $E_{\mathrm{HOMO}}=-\left(E_{\mathrm{OX}}+4.35\right)$ $\mathrm{eV}$ and $E_{\mathrm{LUMO}}=-\left(E_{\mathrm{red}}+4.35\right) \mathrm{eV}$. As a result, the HOMO energy levels ( $E_{\mathrm{HOMO}}$ ) were estimated at $-5.27 \mathrm{eV}$ for Ph(DPP$\mathrm{Th})_{2},-5.30 \mathrm{eV}$ for $\mathrm{Ph}(\mathrm{DPP}-\mathrm{Py})_{2},-5.42 \mathrm{eV}$ for $\mathrm{Ph}(\mathrm{DPP}-\mathrm{ThCN})_{2}$ and $-5.35 \mathrm{eV}$ for $\mathrm{Ph}(\mathrm{DPP}-\mathrm{ThR})_{2}$, respectively. Compared to the $\mathrm{Ph}(\mathrm{DPP}-\mathrm{Th})_{2}$ and $\mathrm{Ph}(\mathrm{DPP}-\mathrm{Py})_{2}, \mathrm{Ph}(\mathrm{DPP}-\mathrm{ThCN})_{2}$ and $\mathrm{Ph}(\mathrm{DPP}-\mathrm{ThR})_{2}$ exhibit a significantly decreased $E_{\mathrm{HOMO}}$ levels, which means that two terminal acceptors of ThCN and ThR play a positive role in reducing HOMO levels of its small molecules with DPP-Ph-DPP building block central core due to the strong electron withdrawing ability. Meanwhile, the LUMO energy levels of Ph(DPPTh $)_{2}, \mathrm{Ph}(\mathrm{DPP}-\mathrm{Py})_{2}, \mathrm{Ph}(\mathrm{DPP}-\mathrm{ThCN})_{2}$ and $\mathrm{Ph}(\mathrm{DPP}-\mathrm{ThR})_{2}$ were calculate to be $-3.34 \mathrm{eV},-3.16 \mathrm{eV},-3.45 \mathrm{eV}$ and $-3.44 \mathrm{eV}$, and the corresponding electrochemical bandgaps $\left(E_{\mathrm{g}}^{\mathrm{ev}}\right)$ were estimated to be $1.93 \mathrm{eV}, 2.14 \mathrm{eV}, 1.98 \mathrm{eV}$ and $1.91 \mathrm{eV}$, respectively. This discrepancy between the optical and electrochemical band gaps might be induced by the presence of an energy barrier at the interface between the small molecule film and the electrode surface [45].

\subsection{Photovoltaic properties}

To investigate the photovoltaic properties of these small molecules, BHJ OSCs were fabricated with a general device structure of ITO/PEDOT:PSS/active layer/Ca/Al under simulated AM $1.5 \mathrm{G}$, $100 \mathrm{~mW} \mathrm{~cm}^{-2}$ irradiation. The active layer consisted of DPP-PhDPP-based donors materials, Ph(DPP-Th $)_{2}$, Ph(DPP-Py $)_{2}$, Ph(DPPThCN $)_{2}$ and $\mathrm{Ph}(\mathrm{DPP}-\mathrm{ThR})_{2}$, and an acceptor material, $(6,6)$-phenyl butyric acid methyl ester (PCBM). The device area was $0.1 \mathrm{~cm}^{2}$, as defined by a shadow mask. The photovoltaic performances of OSCS are strongly affected by the processing parameters, including the $\mathrm{D} /$ A ratios $(w / w)$, annealing temperatures, spin-coating rates, and DIO additive concentrations [2]. Optimized parameters were obtained, and Figs. S1-S4 depict the current density-voltage $(J-V)$ characteristics of small molecules/PCBM-based devices at different ratios, annealing temperatures, spin-coating rates, and DIO additive concentrations, respectively. The resulting photovoltaic data are summarized in Tables S1-S4, respectively. As shown in Fig. 4, these devices exhibited typical $J-V$ characteristics under these optimized conditions. Device parameters, such as $J_{\mathrm{sc}}, V_{\mathrm{oc}}, F F$ and PCE, were deduced from the $J-V$ characteristics and are summarized in Table 2.

As shown in Fig. 4, the $\mathrm{Ph}(\mathrm{DPP}-\mathrm{Th})_{2} / \mathrm{PC}_{60} \mathrm{BM}$ and $\mathrm{Ph}(\mathrm{DPP}-\mathrm{Py})_{2} /$ $\mathrm{PC}_{71} \mathrm{BM}$-based devices exhibited better photovoltaic properties compared to the $\mathrm{Ph}(\mathrm{DPP}-\mathrm{ThCN})_{2} / \mathrm{PC}_{71} \mathrm{BM}$ and $\mathrm{Ph}(\mathrm{DPP}-\mathrm{ThR})_{2} /$ $\mathrm{PC}_{71} \mathrm{BM}$-based devices, which was attributed to significant increases in the $J_{\mathrm{sc}}$ (from 2.11 and $2.21 \mathrm{~mA} \mathrm{~cm}^{-2}$ to 5.63 and 


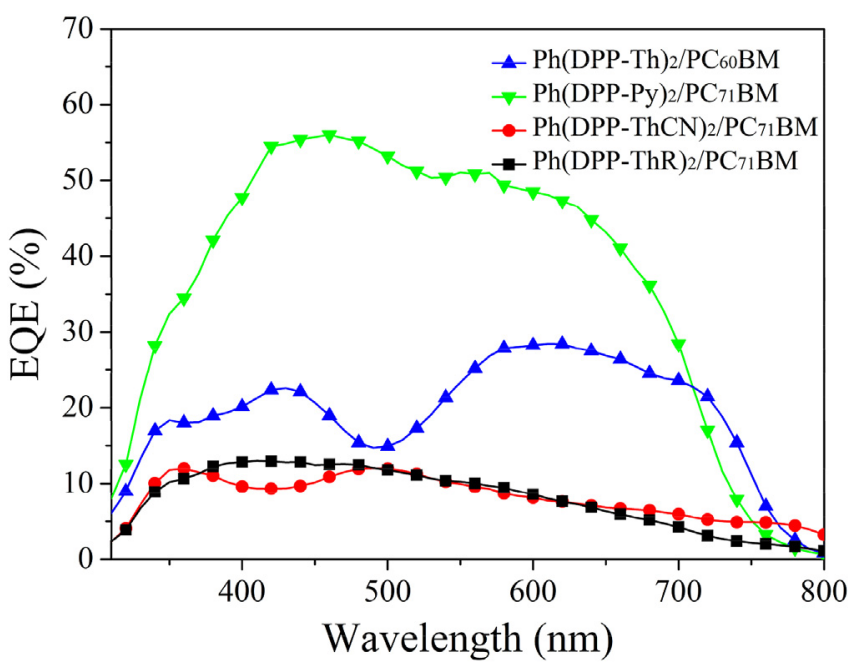

Fig. 5. EQE curves of the small molecules/PCBM-based devices.

$10.55 \mathrm{~mA} \mathrm{~cm}^{-2}$ ) of their OSCs. As result, a maximum PCE of $3.22 \%$ was obtained with $V_{\text {oc }}$ of $0.85 \mathrm{~V}, J_{\mathrm{sc}}$ of $10.55 \mathrm{~mA} \mathrm{~cm}{ }^{-2}$, and $F F$ of $39 \%$ in the $\mathrm{Ph}(\mathrm{DPP}-\mathrm{Py})_{2} / \mathrm{PC}_{71} \mathrm{BM}$-based device. Promisingly, we note that the PCE of optimized $\mathrm{Ph}(\mathrm{DPP}-\mathrm{Py})_{2} / \mathrm{PC}_{71} \mathrm{BM}$ solar cells is $3.22 \%$, which is higher than the results obtained by Chen for the same blend (3.0\%) [6].

As shown in Fig. S5, dissolution properties of these $\mathrm{SMs}$ at $\mathrm{CHCl}_{2}$ with a same concentration of $\sim 2 \mathrm{mg} / \mathrm{mL}$ under RT were investigated by a reported method [46]. These SMs have a solubility ranking of $\mathrm{Ph}(\mathrm{DPP}-\mathrm{ThR})_{2}<\mathrm{Ph}(\mathrm{DPP}-\mathrm{ThCN})_{2}<\mathrm{Ph}(\mathrm{DPP}-\mathrm{Py})_{2}<\mathrm{Ph}(\mathrm{DPP}-\mathrm{Th})_{2}$, and we can clearly see that $\mathrm{Ph}(\mathrm{DPP}-\mathrm{Th})_{2}$ and $\mathrm{Ph}(\mathrm{DPP}-\mathrm{Py})_{2}$ show good solubility properties, although $\mathrm{Ph}(\mathrm{DPP}-\mathrm{ThCN})_{2}$ and $\mathrm{Ph}(\mathrm{DPP}-\mathrm{ThR})_{2}$ have lots of residual particles in the solution. Opposite to the ranking of melting temperatures, and these characteristics were reflected during photovoltaic device fabrication. In accordance with these results, $\mathrm{Ph}(\mathrm{DPP}-\mathrm{Th})_{2}$ and $\mathrm{Ph}(\mathrm{DPP}-\mathrm{Py})_{2}$ OSCs performed better than $\mathrm{Ph}(\mathrm{DPP}-\mathrm{ThCN})_{2}$ and $\mathrm{Ph}(\mathrm{DPP}-\mathrm{ThR})_{2}$ OSCs. The worse photovoltaic performance of $\mathrm{Ph}(\mathrm{DPP}-\mathrm{ThCN})_{2}$ and $\mathrm{Ph}(\mathrm{DPP}-\mathrm{ThR})_{2}$ compared to $\mathrm{Ph}(\mathrm{DPP}-\mathrm{Th})_{2}$ and $\mathrm{Ph}(\mathrm{DPP}-\mathrm{Py})_{2}$ could be attributed to the surface morphology of the active layer is restricted by the poorer solubility in $\mathrm{CHCl}_{3}$ lead to lower $J_{\mathrm{sc}}$ value of the latter two molecules, which limited their device performances [47].

To better understand why the $\mathrm{Ph}(\mathrm{DPP}-\mathrm{Py})_{2} / \mathrm{PC}_{71} \mathrm{BM}$ based devices displayed high $J_{\mathrm{sc}}$ and PCE values, the external quantum efficiency (EQE) curves of the small molecules/PCBM based devices at the optimal conditions were measured. As shown in Fig. 5, all of the devices showed relatively wide $E Q E$ spectra in the range of 300-800 $\mathrm{nm}$ and were consistent with their corresponding $\mathrm{UV}-\mathrm{Vis}$ absorption profile (Fig. 3). Notably, a maximum EQE of $56 \%$
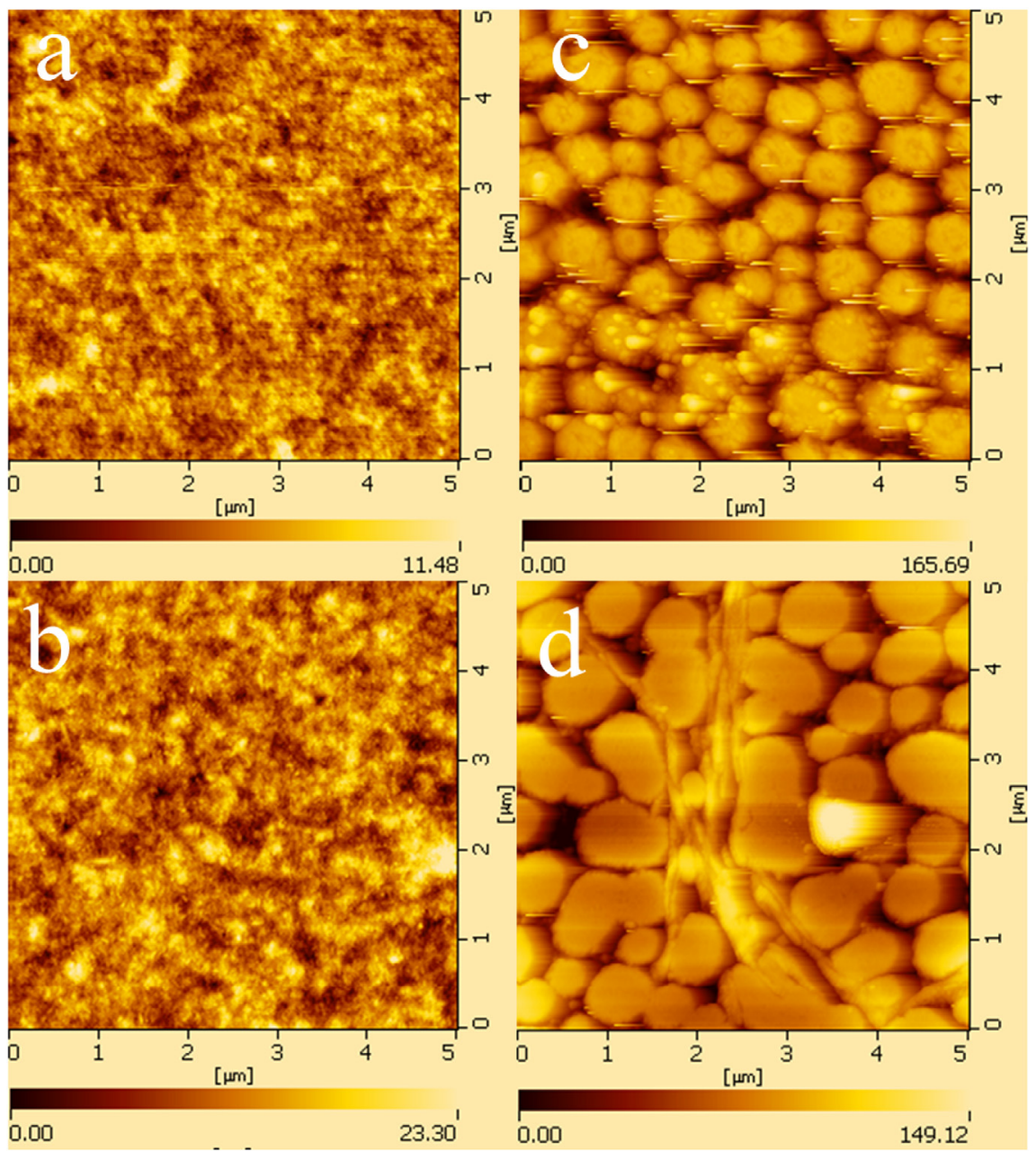

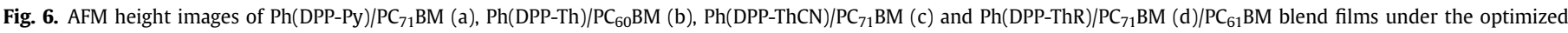
condition, respectively. 
at $460 \mathrm{~nm}$ for the $\mathrm{Ph}$ (DPP-Py $)_{2} / \mathrm{PC}_{71} \mathrm{BM}$ based device, corresponding to high $E Q E$ over $40 \%$ in a broad range from 374 to $664 \mathrm{~nm}$, was observed, whereas the other three small molecules based devices showed lower $E Q E$ values. According to the EQE curves and the solar irradiation spectrum, the integral $J_{\mathrm{sc}}$ values of the four SMs based devices are 10.17, 5.03, 2.21 and $2.11 \mathrm{~mA} \mathrm{~cm}^{-2}$, respectively, which are coincident with the measured $J_{\mathrm{sc}}$ values from $J-V$ curves within a $4 \%$ error.

To get some ideas about the influence of the chemical structures on hole mobilities $\left(\mu_{\mathrm{h}}\right)$ of these photoactive layers, the space charge limited current (SCLC) method were carried in the hole devices with a structure of ITO/PEDOT:PSS/active layer/Au at the optimized condition [44]. As showed in Fig. S6 and Table S6, the $\mu_{\mathrm{h}}$ values of the four SMs based on the hole devices are proportional to the FF values based on the OSCs. $\mathrm{Ph}(\mathrm{DPP}-\mathrm{Th})_{2}$ shows the highest $\mu_{\mathrm{h}}$ of $8.42 \times 10^{-5} \mathrm{~cm}^{2} \mathrm{~V}^{-1} \mathrm{~s}^{-1}$, which can be attributed to the good solubility and the plane of thiophene terminal [41]. $\mathrm{Ph}(\mathrm{DPP}-\mathrm{Th})_{2}$ and $\mathrm{Ph}(\mathrm{DPP}-\mathrm{Th})_{2}$ shows that the lower $\mu_{\mathrm{h}}$ can be attributed to the poor solubility of terminal acceptors of ThCN and ThR. As we known, the poor dissolution properties of the compounds will severely restrict the morphology of the films lead to a reduced $\mu_{\mathrm{h}}$ and FF [47]. $\mathrm{Ph}(\mathrm{DPP}-\mathrm{Py})_{2}$ shows the lowest $\mu_{\mathrm{h}}$ of $3.27 \times 10^{-5} \mathrm{~cm}^{2} \mathrm{~V}^{-1} \mathrm{~s}^{-1}$, which can be attributed to the twisted conjugate structure of 1 substituted pyrene terminal [48].

In order to get some ideas about the influence of the chemical structures on their surface morphologies, tapping mode atomic force microscope (AFM) measurements were carried out to investigate the surface morphologies of the blend films of compounds/ $\mathrm{PC}_{71} \mathrm{BM}$ processed under the optimized condition. The height images $\left(5 \times 5 \mu \mathrm{m}^{2}\right)$ are shown in Fig. 6 . The root mean square (RMS) roughness was determined to be $1.38,2.75,19.15$ and $21.75 \mathrm{~nm}$ for the Ph(DPP-Py $)_{2}, \mathrm{Ph}(\mathrm{DPP}-\mathrm{Th})_{2}, \mathrm{Ph}(\mathrm{DPP}-\mathrm{ThCN})_{2}$ and $\mathrm{Ph}(\mathrm{DPP}-\mathrm{ThR})_{2}$ based blend films, respectively. A smoother surface was observed for the $\mathrm{Ph}(\mathrm{DPP}-\mathrm{Py})_{2}$ based blend film. In general, the smoother morphology indicates finer phase separation, which would promote the exciton dissociation efficiency, resulting in increasing the light response and $J_{\mathrm{sc}}[6]$. Therefore, a higher $J_{\mathrm{sc}}$ of $10.55 \% \mathrm{~mA} \mathrm{~cm}^{-2}$ for the Ph(DPP-Py $)_{2}$ based device was ascribed to a well-ordered nanoscale morphology, and the corresponding PCE was up to $3.22 \%$.

\section{Conclusion}

Four novel DPP-based SMs, Ph(DPP-Th $)_{2}$, Ph(DPP-Py) 2 , Ph(DPPThCN $)_{2}$ and $\mathrm{Ph}(\mathrm{DPP}-\mathrm{ThR})_{2}$, were obtained, in which DPP-Ph-DPP was used as the central core, and Th, Py, ThCN and ThR were used as the different molecular terminals, respectively. All of SMs exhibit broad absorption spectra from the visible to near-infrared region, and $\mathrm{Ph}(\mathrm{DPP}-\mathrm{ThR})_{2}$ showed the minimum optical band gap of $1.44 \mathrm{eV}$. The SMs with acceptor terminal units (ThCN or ThR) have much deeper HOMO energy levels compared to those with donor terminal units (Py or Th). A maximum PCE of 3.22\%, a $J_{\text {sc }}$ of $10.55 \% \mathrm{~mA} \mathrm{~cm}^{-2}, V_{\mathrm{oc}}$ of $0.85 \mathrm{~V}$ and $F F$ of $39 \%$ were obtained in the $\mathrm{Ph}$ (DPP-Py $)_{2} / \mathrm{PC}_{71} \mathrm{BM}$ based cell. These results indicate a valuable guideline for rational design of solution-processed SMs for OSCs.

\section{Acknowledgments}

Thanks to the financial supports from the Major Cultivation and General Programs of the National Natural Science Foundation of China (51573154, 91233112, 21172187, 51403178), the Program for Innovative Research Cultivation Team in University of Ministry of Education of China (1337304), the Innovation Group in Hunan Natural Science Foundation (12JJ7002), the Natural Science Foundation of Hunan (14JJ4019, 2015JJ3113), Open Project for the National Key Laboratory of Luminescent Materials and Devices (2014- skllmd-10), Research Foundation of Hunan Education Bureau (13A102, 14C1099).

\section{Appendix A. Supplementary data}

Supplementary data related to this article can be found at http:// dx.doi.org/10.1016/j.dyepig.2015.10.006.

\section{References}

[1] Walker B, Kim C, Nguyen TQ. Small molecule solution-processed bulk heterojunction solar cells. Chem Mater 2011;23:470-82.

[2] Fan Q, Xiao M, Liu Y, Su W, Gao H, Tan H, et al. Improved photovoltaic performance of 2D-conjugated benzodithiophene-based polymer by the side chain engineering at quinoxaline. Polym Chem 2015:6:4290-8.

[3] Fan L, Cui R, Jiang L, Zou Y, Li Y, Qian D. A new small molecule with indolone chromophore as the electron accepting unit for efficient organic solar cell. Dyes Pigments 2015;13:458-64.

[4] Hendriks KH, Heintges GHL, Gevaerts VS, Wienk MM, Janssen RAJ. High-molecular-weight regular alternating diketopyrrolopyrrole-based terpolymers for efficient organic solar cells. Angew Chem Int Ed 2013;52:8341-4.

[5] Yin QR, Miao JS, Wu Z, Chang ZF, Wang JL, Wu HB, et al. Rational design of diketopyrrolopyrrole-based oligomers for high performance small molecular photovoltaic materials via extended framework and multiple fluorine substitution. J Mater Chem A 2015;3:11575-86.

[6] Liu SY, Liu WQ, Xu JQ, Fan CC, Fu WF, Ling J, et al. Pyrene and diketopyrrolopyrrole-based oligomers synthesized via direct arylation for OSC applications. ACS Appl Mater Interfaces 2014;6:6765-75.

[7] You JB, Dou LT, Yoshimura K, Kato T, Ohya K, Moriarty T, et al. A polymer tandem solar cell with $10.6 \%$ power conversion efficiency. Nat Commun 2013;4:1446-55.

[8] Liu Y, Zhao J, Li Z, Mu C, Ma W, Hu H, et al. Aggregation and morphology control enables multiple cases of high-efficiency polymer solar cells. Nat Commun 2014;5:5293-301.

[9] You JB, Chen CC, Hong ZR, Yoshimura K, Ohya K, Xu R, et al. 10.2\% power conversion efficiency polymer tandem solar cells consisting of two identical sub-cells. Adv Mater 2013;25:3973-8.

[10] Fan HJ, Zhu XZ. Development of small-molecule materials for highperformance organic solar cells. Sci China Chem 2015;58:922-36.

[11] Kan B, Li M, Zhang Q, Liu F, Wan X, Wang Y, et al. A series of simple oligomerlike small molecules based on oligothiophenes for solution-processed solar cells with high efficiency. J Am Chem Soc 2015;137:3886-93.

[12] Zhou JY, Zuo Y, Wan XJ, Long GK, Zhang Z, Ni W, et al. Solution processed and high performance organic solar cells using small molecules with benzodithiophene unit. J Am Chem Soc 2013;135:8484-7.

[13] Li WW, Hendriks KH, Furlan A, Roelofs WSC, Meskers SCJ, Wienk MM, et al. Effect of the fibrillar microstructure on the efficiency of high molecular weight diketopyrrolopyrrole-based polymer solar cells. Adv Mater 2014;26:1565-70.

[14] Zhang YM, Tan H, Xiao MJ, Bao XC, Tao Q, Wang YF, et al. D-A-Ar-type small molecules with enlarged $\pi$-system of phenanthrene at terminal for highperformance solution processed organic solar cells. Org Electron 2014;15: 1173-83.

[15] Chen MR, Fu WF, Shi MM, Hu XL, Pan JY, Ling J, et al. An ester-functionalized diketopyrrolopyrrole molecule with appropriate energy levels for application in solution-processed organic solar cells. J Mater Chem A 2013;1:105-11.

[16] Liu Y, Dub XY, Xiao Z, Cao JM, Tan ST, Zuo QQ et al. Solution processable low bandgap small molecule donors with naphthalene end-groups for organic solar cells, solution processable low bandgap small molecule donors with naphthalene end-groups for organic solar cells. Synth Met 2012;162: $1665-71$.

[17] Lin YZ, Ma LC, Li YF, Liu YQ, Zhu DB, Zhan XW. A solution processable small molecule based on benzodithiophene and diketopyrrolopyrrole for highperformance organic solar cells. Adv Energy Mater 2013;3:1166-70.

[18] Shi HQ, Gu ZW, Gu X, Pan HB, Pan JY, Hu XL, et al. Effect of end-groups on the photovoltaic property of diphenylsubstituted diketopyrrolopyrrole derivatives. Synth Met 2014;188:66-71.

[19] Zhou R, Li QD, Li XC, Lu XM, Wang LP, Zhang CH, et al. Solution-processable diketopyrrolopyrrole dye molecule with (fluoronaphthyl)thienyl end groups for organic solar cells. Dyes Pigments 2014;101:51-7.

[20] Ripaud E, Demeter D, Rousseau T, Boucard CE, Allain M, Po R, et al. Structureproperties relationships in conjugated molecules based on- diketopyrrolopyrrole for organic photovoltaics. Dyes Pigments 2012;95:126-33.

[21] Qiao Y, Guo Y, Yu C, Zhang F, Xu W, Liu Y, et al. Diketopyrrolopyrrole- containing quinoidal small molecules for high-performance, air-stable and solution-processable n-channel organic field-effect transistors. J Am Chem Soc $2012 ; 134: 4084-7$.

[22] Zhong H, Smith J, Rossbauer S, White AJP, Anthopoulos TD, Heeney M. Airstable and high-mobility n-channel organic transistors based on smallmolecule/polymer semiconducting blends. Adv Mater 2012;24:3205-11.

[23] Qu S, Qin C, Islam A, Wu Y, Zhu W, Hua J, et al. A novel D-A- $\pi$-A organic sensitizer containing a diketopyrrolopyrrole unit with a branched alkylchain 
for highly efficient and stable dye-sensitized solar cells. Chem Commun 2012;48:6972-4.

[24] Favereau L, Warnan J, Anne FB, Pellegrin Y, Blart E, Jacquemin D, et al. Diketopyrrolopyrrole-zinc porphyrin, a tuned panchromatic association for dyesensitized solar cells. J Mater Chem A 2013;1:7572-5.

[25] Deng L, Wu W, Guo H, Zhao J, Ji S, Zhang X, et al. Colorimetric and ratiometric fluorescent chemosensor based on diketopyrrolopyrrole (DPP) for selective detection of thiols: an experimental and theoretical study. J Org Chem 2011;76:9294-304.

[26] Walker B, Liu J, Kim C, Welch GC, Park JK, Lin J, et al. Optimization of energy levels by molecular design: evaluation of bis-diketopyrrolopyrrole molecular donor materials for bulk heterojunction solar cells. Energy Environ Sci 2013;6: 952-62.

[27] Zhang L, Zeng S, Yin L, Ji C, Li K, Li Y, et al. The synthesis and photovoltaic properties of A-D-A-type small molecules containing diketopyrrolopyrrole terminal units. New J Chem 2013:37:632-9.

[28] Loser S, Bruns CJ, Miyauchi H, Ortiz RP, Favchetti A, Stupp SI, et al. A naphthodithiophene-diketopyrrolopyrrole donor molecule for efficient solution-processed solar cells. J Am Chem Soc 2011;133:8142-5.

[29] Lan SC, Raghunath P, Lu YH, Wang YC, Lin SW, Liu CM, et al. Symmetry and coplanarity of organic molecules affect their packing and photovoltaic properties in solution-processed solar cells. ACS Appl Mater Interfaces 2014;6: 9298-306.

[30] Chen YH, Du ZK, Chen WC, Liu Q, Sun L, Sun ML, et al. Benzo[1,2-b:4,5- $\left.b^{\prime}\right]$ dithiophene and benzotriazole based small molecule for solution-processed organic solar cells. Org Electron 2014;15:405-13.

[31] Aytun T, Barreda L, Ruiz-Carreter A, Lehrman JA, Stupp SI. Improving solar cell efficiency through hydrogen bonding: a method for tuning active layer morphology. Chem Mater 2015;27:1201-9.

[32] Vybornyi O, Jiang Y, Baert F, Demeter D, Roncali J, Blanchard P, et al. Solutionprocessable thienoisoindigo-based molecular donors for organic solar cells with high open-circuit voltage. Dyes Pigments 2015;115:17-22.

[33] Kim JH, Kim HU, Kang IN, Lee SK, Moon SJ, Shin WS, et al. Incorporation of pyrene units to improve hole mobility in conjugated polymers for organic solar cells. Macromolecules 2010;45:8628-38.

[34] Feng X, Hu JY, Iwanaga F, Seto N, Redshaw C, Elsegood MRJ, et al. Blueemitting butterfly-shaped 1,3,5,9-tetraarylpyrenes: synthesis, crystal structures and photophysical properties. Org Lett 2013;15:1318-21.

[35] Sonar P, Soh MS, Cheng YH, Henssler JT, Sellinger A. 1,3,6,8-Tetrasubstituted pyrenes: solution-processable materials for application in organic electronics. Org Lett 2010;12:3292-5.
[36] Uchimura M, Watanabe Y, Araoka F, Watanabe J, Takezoe H, Konishi G. Development of laser dyes to realize low threshold in dye-doped cholesteric liquid crystal lasers. Adv Mater 2010;22:4473-8.

[37] Kim HU, Kim JH, Kang H, Grimsdale AC, Kim BJ, Yoon SC, et al. Naphthaleneanthracene-, and pyrene-substituted fullerene derivatives as electron acceptors in polymer-based solar cells. ACS Appl Mater Interfaces 2014;6: 20776-85.

[38] Teresa M, Duarte F, Mullen K. Pyrene-based materials for organic electronics. Chem Rev 2011;111:7260-314.

[39] Zou L, Wang XY, Shi K, Wang JY, Pei J. Fusion at the non-k-region of pyrene: an alternative strategy to extend the $\pi$-conjugated plane of pyrene. Org Lett 2013; 15:4378-81.

[40] Fan Q, Liu Y, Xiao M, Tan H, Wang Y, Su W, et al. Donor-acceptor copolymers based on benzo[1,2-b:4,5- $\left.b^{\prime}\right]$ dithiophene and pyrene-fused phenazine for high-performance polymer solar cells. Org Electron 2014;15:3375-83.

[41] Fan Q Cui J, Liu Y, Su W, Wang Y, Tan H, et al. Synthesis and photovoltaic properties of two star-shaped molecules involving phenylquinoxaline as core and triphenylamine and thiophene units as arms. Synth Met 2015;204:25-31.

[42] Lee OP, Yiu AT, Beaujuge PM, Woo CH, Holcombe TW, Millstone JE, et al. Efficient small molecule bulk heterojunction solar cells with high fill factors via pyrene-directed molecular self-assembly. Adv Mater 2011;23:5359-63.

[43] Liu YS, Chen CC, Hong ZR, Gao J, Yang Y, Zhou HP, et al. Solution-processed small-molecule solar cells: breaking the $10 \%$ power conversion efficiency. Sci Rep 2013;3:3356-9.

[44] Fan Q, Liu Y, Xiao M, Su W, Gao H, Chen J, et al. Enhancing photovoltaic properties of terpolymers containing benzo[ $\left.1,2-b: 4,5-b^{\prime}\right]$ dithiophene, phenanthro[4,5-abc]phenazine and benzo[c] $[1,2,5]$ thiadiazole with a changing substituents. J Mater Chem C 2015;3:6240-8.

[45] Fan Q, Li M, Yang P, Liu Y, Xiao M, Wang X, et al. Acceptor-donor-acceptor small molecules containing benzo[1,2-b:4,5- $\left.b^{\prime}\right]$ dithiophene and rhodanine units for solution processed organic solar cells. Dyes Pigments 2015;116: 13-9.

[46] Walker B, Tamayo A, Duong DT, Dang X, Kim C, Granstrom J, et al. A systematic approach to solvent selection based on cohesive energy densities in a molecular bulk heterojunction system. Adv Energy Mater 2011;1:221-9.

[47] Dou L, Chen C, Yoshimura K, Ohya K, Chang W, Gao J, et al. Synthesis of $5 \mathrm{H}_{-}$ dithieno[3,2-b: $\left.2^{\prime}, 3^{\prime}-d\right]$ pyran as an electron-rich building block for donoracceptor type low-bandgap polymers. Macromolecules 2013;46:3384-90.

[48] Mun J, Cho I, Lee D, Yoon W, Kwon O, Lee C, et al. Acetylene-bridged D-A-D type small molecule comprising pyrene and diketopyrrolopyrrole for high efficiency organic solar cells. Org Electron 2013;14:2341-7. 